\title{
Vitamin D, infections and immunity
}

\author{
Aiten Ismailova ${ }^{1}$ John H. White ${ }^{1,2}$ \\ Accepted: 10 July 2021 / Published online: 29 July 2021 \\ (c) The Author(s) 2021
}

\begin{abstract}
Vitamin D, best known for its role in skeletal health, has emerged as a key regulator of innate immune responses to microbial threat. In immune cells such as macrophages, expression of CYP27B1, the 25-hydroxyvitamin D 1 $\alpha$-hydroxylase, is induced by immune-specific inputs, leading to local production of hormonal 1,25-dihydroxyvitamin $\mathrm{D}(1,25 \mathrm{D})$ at sites of infection, which in turn directly induces the expression of genes encoding antimicrobial peptides. Vitamin D signaling is active upstream and downstream of pattern recognition receptors, which promote front-line innate immune responses. Moreover, 1,25D stimulates autophagy, which has emerged as a mechanism critical for control of intracellular pathogens such as $M$. tuberculosis. Strong laboratory and epidemiological evidence links vitamin D deficiency to increased rates of conditions such as dental caries, as well as inflammatory bowel diseases arising from dysregulation of innate immune handling intestinal flora. $1,25 \mathrm{D}$ is also active in signaling cascades that promote antiviral innate immunity; $1,25 \mathrm{D}$-induced expression of the antimicrobial peptide CAMP/LL37, originally characterized for its antibacterial properties, is a key component of antiviral responses. Poor vitamin D status is associated with greater susceptibility to viral infections, including those of the respiratory tract. Although the severity of the COVID-19 pandemic has been alleviated in some areas by the arrival of vaccines, it remains important to identify therapeutic interventions that reduce disease severity and mortality, and accelerate recovery. This review outlines of our current knowledge of the mechanisms of action of vitamin D signaling in the innate immune system. It also provides an assessment of the therapeutic potential of vitamin D supplementation in infectious diseases, including an up-to-date analysis of the putative benefits of vitamin D supplementation in the ongoing COVID-19 crisis.
\end{abstract}

Keywords Vitamin D · Inflammation · Antibacterial · Antiviral · COVID-19 · Cathelicidin · $\beta$-defensin $2 \cdot$ NOD2

\section{Introduction}

Vitamin D is obtained from few dietary sources such as oily fish and egg yolks, or from photochemical and thermal transformation of the cholesterol precursor 7-dehydrocholesterol in skin exposed to ultraviolet B radiation. However, the angle of the sun has to be greater than $45^{\circ}$ for efficient synthesis of vitamin $\mathrm{D}$ to occur in skin. Consequently, it cannot be produced at latitudes of $45^{\circ}$ or higher (which includes Canada and several European countries) during 6 months of the year or longer, a period known as vitamin D winter [1]. Vitamin $\mathrm{D}$ was discovered for its capacity to prevent rickets, a disease

John H. White

john.white@mcgill.ca

1 Departments of Physiology, McGill University, Montreal, Qc, Canada

2 Departments of Medicine, McGill University, Montreal, Qc, Canada of bone growth that arises from insufficient uptake of dietary calcium [2]. Relevant to this review, a diagnosis of rickets is also associated with increased risk of development of diseases unrelated to calcium homeostasis, notably a number of immune disorders [3]. Unfortunately, vitamin D deficiency remains widespread; a study of adolescents in several European countries found that vitamin D levels in $80 \%$ of subjects were below the threshold of sufficiency. Moreover, over $40 \%$ were considered deficient or severely deficient [4]. This is consistent with estimates of dietary intakes in Europe, which were generally deficient in vitamin D [5], and the vitamin D status of the general European population, where vitamin D deficiency is widespread and most prevalent in dark-skinned subgroups [6]. Even in more southern countries, such as India, poor vitamin D status is common [7].

The vitamin D metabolite measured in most studies is the major form in serum, 25-hydroxyvitamin $\mathrm{D}$ (25D). 25D has a circulating half-life of several weeks. Consequently, its levels vary seasonally, and it represents a reliable indicator of 
vitamin D status [8]. 25D is generated by the mostly hepatic 25-hydroxylation of dietary or cutaneous vitamin D catalyzed by CYP2R1 and other enzymes $[9,10]$. The active metabolite of vitamin $\mathrm{D}, 1,25$-dihydroxyvitamin $\mathrm{D}(1,25 \mathrm{D})$, is generated in peripheral tissues in a highly regulated manner by the unique $1 \alpha$-hydroxylase CYP27B1 [11]. Originally CYP27B1 was considered to be found solely in the kidney, however this perception changed with evidence for its widespread presence in tissues unrelated to calcium homeostasis $[11,12] .1,25 \mathrm{D}$ signals through the nuclear receptor vitamin D receptor (VDR), a ligand-regulated transcription factor [13]. Gene expression profiling studies have shown that $1,25 \mathrm{D}$ signaling directly and indirectly regulates over 1,000 genes in the human genome [14]. The most robustly induced 1,25D target gene is CYP24Al, which represents a negative feedback loop as it encodes the enzyme that 24-hydroxylates 25D and 1,25D to initiate their catabolism.

Importantly, the VDR and CYP27B 1 are broadly expressed in many tissues that are not implicated in calcium homeostasis [11, 15]. Indeed, several non-classical, extraskeletal actions have been attributed to vitamin $\mathrm{D}$ signaling. One of the most prominent of these is its role in regulating both the innate and adaptive arms of the immune system. This has gained added prominence over the past year or so in the wake of the COVID-19 pandemic, the disease caused by infection with the SARS-CoV-2 coronavirus, and a number of clinical trials have been conducted to investigate links between vitamin D and COVID-19. As detailed below, there is extensive and growing molecular evidence for a role of vitamin D signaling in the stimulation of innate immune responses to pathogen threat. Moreover, this is supported by an expanding body of clinical data. The goals of the present review are to explore the molecular basis for innate immune regulation by $1,25 \mathrm{D}$, and the clinical evidence that vitamin $\mathrm{D}$ signaling promotes antibacterial and antiviral innate immunity, with a specific focus on COVID-19.

\section{1,25D signaling contributes to innate immunity}

Critical evidence for a physiological role of vitamin D signaling in immune system regulation came from observations that CYP27B1 expression in immune cells is controlled by a series of immune inputs (Fig. 1). The first compelling evidence for the importance of $1,25 \mathrm{D}$ signaling in innate immunity stems from a 2000 study by Mathieu and coworkers, who showed that murine Cyp27b1 expression was inducible by bacterial lipopolysacharide (LPS) and interferon $\gamma$ (IFN- $\gamma$ ), a T cell cytokine released by pro-inflammatory Th1 cells [16]. In 2006, Modlin's group exposed human macrophages in vitro to the ligand of the pattern recognition receptor toll-like receptor 2 (TLR2). This resulted in increased VDR and CYP27BI expression, as well as generation of endogenous $1,25 \mathrm{D}$ from 25D present in human serum [17]. Pattern recognition receptors (PRRs) are intracellular or transmembrane proteins that recognize microorganism-specific patterns or endogenous danger-associated molecules such as extracellular ATP, or cytoplasmic or endosomal nucleic acids [18]. As such, they are "first-responders" of the innate immune system as ligand
Fig. 1 Antibacterial activity of vitamin $\mathrm{D}$ in monocytic cells. Schematic representation of the antimicrobial actions of vitamin $\mathrm{D}$ in response to bacterial infection. In monocytic cells, there is local production of $1,25 \mathrm{D}$ from circulating $25 \mathrm{D}$, which is under control of pattern recognition receptor signaling. $1,25 \mathrm{D}$ bound to the VDR regulates expression of several genes essential for innate immune defense, including those encoding cytokines, chemokines, antimicrobial peptides and pattern recognition receptors. In addition, $1,25 \mathrm{D}$ suppresses production of proinflammatory cytokines, such as IL-6, preventing an overstimulated immune response. $1,25 \mathrm{D}$ can also induce autophagy, resulting in enhanced bacterial killing

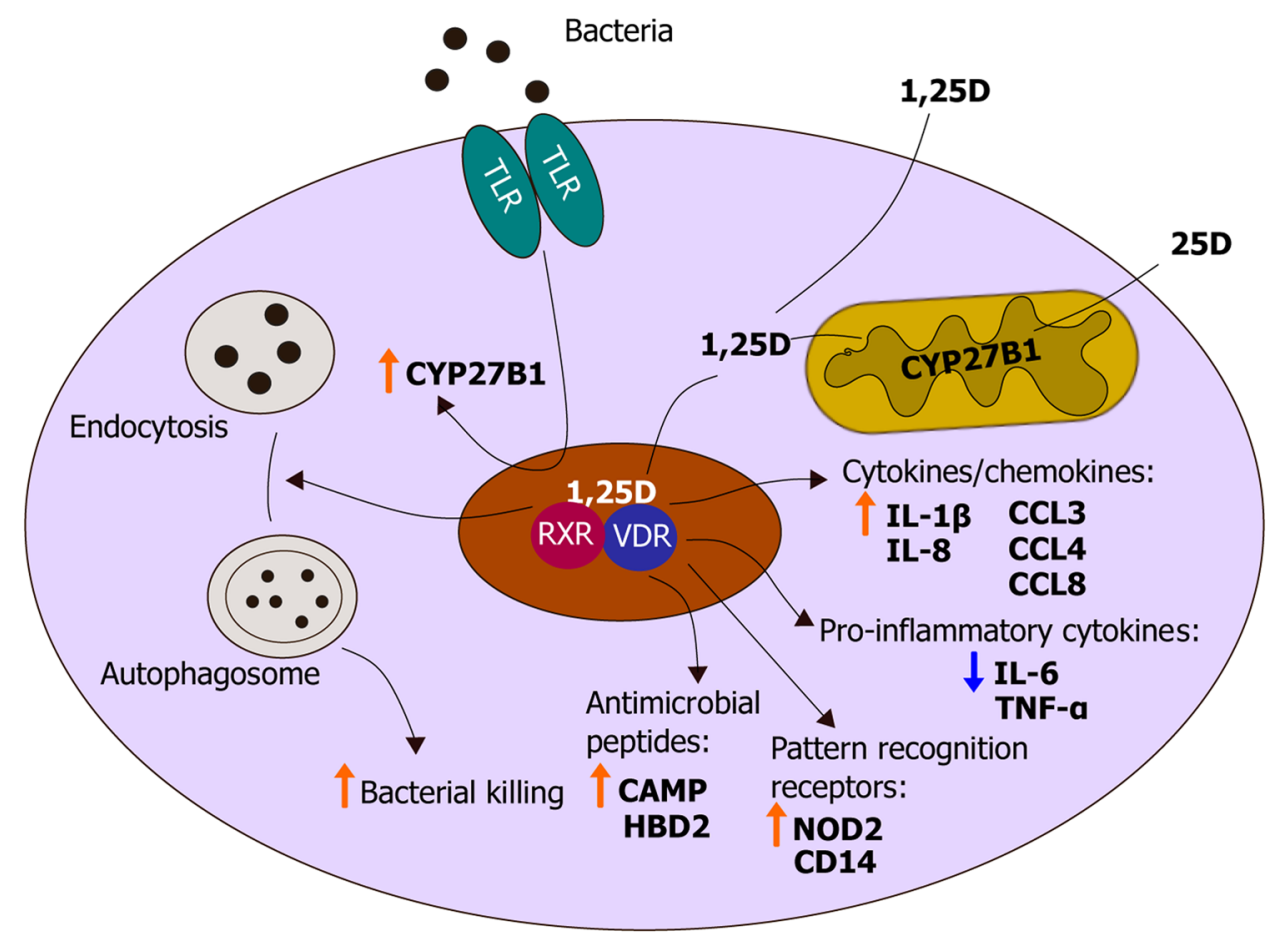


binding to PRRs activate a cascade of signaling events that alert the cell of infection. CYP27B1 transcription in macrophages and dendritic cells is also controlled by a cytokine network that includes IFN- $\gamma[19,20]$. Taken together, these findings reveal that immune production of $1,25 \mathrm{D}$ is regulated by inputs that are unrelated to calcium homeostasis and that local synthesis of $1,25 \mathrm{D}$ and its downstream signaling are integral components of innate immune responses to microbes.

\section{Antibacterial responses to 1,25D}

The last couple of decades of research have shown that locally produced $1,25 \mathrm{D}$, via binding to the VDR, activates transcription of several genes associated with innate immunity. In human and murine cells, the gene encoding CD14, the co-receptor of the PRR TLR4 is strongly induced by 1,25D [21, 22] (Fig. 1). Furthermore, vitamin D signaling boosts expression of TLR2 in keratinocytes, and given that signaling via TLR2 or TLR4 ameliorates vitamin D signaling by increasing VDR and CYP27B1 expression, this constitutes a positive feedback loop [22]. In human macrophages, expression of the C-type lectin mannose receptor is repressed by $1,25 \mathrm{D}$, which hampers infection by the dengue virus [23]. Convincing evidence for a direct regulation of antimicrobial innate immune responses by the hormone originated from finding vitamin $\mathrm{D}$ response elements (VDREs) adjacent to the transcription start sites of two genes that encode antimicrobial peptides (AMPs), cathelicidin antimicrobial peptide (CAMP/LL37) and $\beta$-defensin 2 (DEFB2/DEFB4/HBD2) [24]. A strong induction of CAMP by $1,25 \mathrm{D}$ was observed in several cell lines and human primary cell cultures, whereas $1,25 \mathrm{D}$ appeared to be a secondary inducer of $D E F B 2$, notably enhancing interleukin $1 \beta$ (IL-1 $\beta$ )-induced transcription of the gene [24] (Fig. 1).

Autophagy is an important facet of immune responses to intracellular infections and boosts microbial clearance [25, 26]. In macrophages, branched-chain amino acids (BCAAs), which are essential amino acids, act as nutrient sensors. Recently, we showed that $1,25 \mathrm{D}$ attenuated myeloid cellspecific, BCAA-dependent activation of the major metabolic kinase mammalian Target of Rapamycin (mTOR), which is a repressor of autophagy [27]. Autophagy induced by vitamin D signaling in macrophages (Fig. 1) was dependent on 1,25D-stimulated expression of branched-chain aminotransferase (BCAT1), the enzyme that initiates the catabolism of BCAAs; the effect of $1,25 \mathrm{D}$ on autophagy was eliminated in cells in which $B C A T 1$ had been ablated, thereby implicating enhanced BCAA catabolism in 1,25D-regulated autophagy in macrophages [27]. Collectively, the afore-mentioned results provide a mechanistic rationale for adequate vitamin D levels promoting widespread antimicrobial defense.
Mechanisms of immune signaling by vitamin $\mathrm{D}$ are not conserved among all species. The VDRE in the CAMP gene is present within an Alu repeat, a transposable element found uniquely in primates [28]; the transposition event seemed to have occurred in an early primate progenitor and, consequently, is evolutionarily conserved in Old and New World monkeys, apes and humans. There is also preservation of VDREs in $H B D 2, C A M P$, and NOD2 genes in primates, however, they do not appear to exist in rodents [29]. By the same token, transcription of the HBD2, CAMP, and NOD2 genes is enhanced by $1,25 \mathrm{D}$ in human myeloid and epithelial cells, but not in murine cells [29]. Divergent mechanisms of AMP regulation in mice and humans may be due to the nocturnal nature of mice, which is contrary to daily human activity, enhancing the potential of vitamin D synthesis from the sun's ultraviolet rays [17].

\section{Regulation of pattern recognition receptor and cytokine gene expression by 1,25D}

Other than CD14 and TLR2, mentioned above, vitamin D can induce transcription of the intracellular pathogen sensing protein NOD2/CARD15/IBD1 in monocytes and epithelial cells [30] (Fig. 1). This PRR detects a lysosomal breakdown product of bacterial peptidoglycan known as muramyl dipeptide (MDP), and exposure to 1,25D and MDP initiates $1,25 \mathrm{D}$ and NF- $\mathrm{kB}$-dependent induction of DEFB4 and CAMP in cells that express functional NOD2. In patients with the relapsing inflammatory bowel condition Crohn's disease (CD) carrying inactivating NOD2 mutations, this regulation was abolished [30]. Humans who are heterozygous or homozygous for inactivating mutations of the NOD2 gene carry enhanced risks of developing $\mathrm{CD}$ of threefold and 20 -fold, respectively [31]. Therefore, these findings indicate a link between 1,25D signaling and the pathogenesis of CD. 1,25D-regulation of NOD2 may also aid in combatting mycobacterial infections such as $M$. tuberculosis $(M t b)$; mycobacteria produce the $\mathrm{N}$-glycolyl form of MDP, which binds to NOD2 with greater affinity than the $\mathrm{N}$-acetyl form [32].

$1,25 \mathrm{D}$ also directly induces transcription of the human gene encoding IL-1 $\beta$, which is among the first cytokines generated in response to infection via pathogen-directed activation of the inflammasome [33]. A co-culture of $M t b$ infected macrophages with primary human airway epithelial cells revealed that $1,25 \mathrm{D}$-mediated IL- $1 \beta$ secretion extended survival of infected macrophages (Fig. 1). Other cytokines/ chemokines strongly upregulated by $1,25 \mathrm{D}$ in uninfected and $M t b$ infected macrophages include CCL3, CCL4 and CCL8, as well as the neutrophil chemoattractant, IL-8/CXCL8 [33] (Fig. 1). In $M t b$-infected human peripheral blood 
mononuclear cells, dose-dependent suppression of the proinflammatory cytokines IL-6, TNF- $\alpha$, and IFN- $\gamma$ occurred with 1,25D treatment [34]; a VDR-initiated repression at the mRNA and protein level of the PRRs TLR2, TLR4, Dectin-1 and mannose receptor was postulated as the mechanism. Likewise, LPS-mediated production of pro-inflammatory cytokines IL- 6 and TNF- $\alpha$ in human and rodent monocytes and macrophages was repressed by $1,25 \mathrm{D}[35,36]$ (Fig. 1).

\section{Regulation by 1,25D in other innate immune cells}

Most of the earlier work on vitamin D regulation in the innate immune system was performed in monocytes, macrophages and epithelial cells. Nevertheless, several different cell types express PRRs and possess the essential machinery to produce immune responses following microbial invasion. For instance, neutrophils express VDR mRNA to a similar extent to monocytes, and also induce expression of $C D 14$ and $C A M P$ in the presence of $1,25 \mathrm{D}[24,37]$. Although they do not seem to express substantial levels of CYP27B1, they represent the major source of serum cathelicidin/LL37 encoded by CAMP due to their abundance in the blood [38]. Furthermore, mast cells also express VDR, but contrary to neutrophils, express CYP27B1 as well [39]. IgE-mediated mast-cell derived induction of proinflammatory and vasodilatory mediators in human and murine mast cells was shown to be inhibited by both 25 and 1,25D. Natural killer (NK) cells, which function at the frontier between innate and adaptive immunity, are also responsive to 1,25D signaling [40-42]. In patients with chronic renal failure and vitamin D-resistant rickets, there is dysregulated activity of NK cells, and supplementation with 1,25D is reported to ameliorate and normalize NK function in these patients [40,43]. Moreover, in combination with the synthetic glucocorticoid dexamethasone, 1,25D enhanced expression of the anti-inflammatory cytokine, IL-10 in NK cells, inducing regulatory phenotype regulated by $1,25 \mathrm{D}$ signaling [42]. Globally, these findings demonstrate an important role for $1,25 \mathrm{D}$ innate immune regulation in a variety of immune cells.

\section{Evidence for regulation by 1,25D of antibacterial innate immunity in vivo in humans}

Numerous clinical studies have provided evidence for 1,25D-mediated immune regulation. Pre-clinical data showed that $1,25 \mathrm{D}$ treatment enhanced secretion from cultured epithelial cells of antimicrobial activity against Escherichia coli and the lung pathogen, Pseudomonas aeruginosa [29]. Consistent with these findings, in a single-centre community-based randomised placebo-controlled double-blind trial, vitamin D supplementation (1000 international units per day for 90 days) led to more robust antimicrobial activity of lung airway surface liquid (ASL) [44]. Furthemore, increased ASL antimicrobial activity was observed in the summer-fall season compared to winter-spring, and an anti-LL37 (CAMP) antibody blocked the activity in ASL. In addition, vitamin D supplementation abrogated the seasonality of ASL antimicrobial activity [44]. A study conducted in Sweden reported an association between low vitamin D levels and an increased risk of dental caries. Strikingly, vitamin D status in participants correlated positively with levels of CAMP found in saliva [45]. Another study in Poland found similar results; investigators reported lower prevalence of caries in children supplemented with vitamin D [46]. Subsequently, it was found that CAMP/ LL37 is efficacious against bacterial species that reside in plaque, such as Streptococcus mutans [47]. These findings provide a molecular basis for analyses of vitamin D supplementation trials. Vitamin D deficiency emerged as a risk factor for dental caries in a large-scale umbrella analysis of systematic reviews and meta-analyses of observational studies and randomized trials with vitamin D, which surveyed a total of 137 outcomes [48]. Similarly, a systematic review of controlled clinical trials concluded that vitamin D supplementation reduced rates of dental caries by about $50 \%$ [49].

Crohn's disease arises from defective intestinal innate immunity, and vitamin D deficiency is common in patients with CD [50]. Several small clinical studies have been published providing evidence that vitamin $\mathrm{D}$ supplementation may be beneficial for patients with $\mathrm{CD}$. These have recently been reanalyzed in two meta-analyses. From their survey of 18 randomized clinical trials, $\mathrm{Li}$ et al. found decreased relapse rates in $\mathrm{CD}$ patients treated with vitamin $\mathrm{D}$ relative to controls [51]. Similarily, a systematic review demonstrated low 25D status is associated with increased odds of inflammatory bowel disease (IBD) activity, mucosal inflammation, low quality of life and subsequent clinical relapse in CD patients [52]. These observations are likely to be reinforced in the future as additional findings continue to be published [53]. Recently, in a Korean cohort of IBD patients including those with $\mathrm{CD}$, severe vitamin $\mathrm{D}$ deficiency was linked to an aggressive disease course and increased risk of surgical intervention [54]. These findings are of interest, because inactivating NOD2 mutations frequent in Western patients with CD are not found in affected Koreans (or in Japanese and Chinese CD patients) [55]. Other work in post-operative $\mathrm{CD}$ patients found that higher vitamin $\mathrm{D}$ levels were associated with lower risk of recurrence as measured by endoscopy [56]. Collectively, although it is not yet routine practice [57], these studies argue that vitamin D supplementation should be a part of a treatment plan for patients with $\mathrm{CD}$. 


\section{25D signaling boosts antiviral immunity}

Mechanistically, antiviral innate immunity is similar to its antibacterial counterpart. Specific PRRs sense viral pathogens and activate several downstream signaling events that initiate cytokine, type 1 interferon and antiviral effector responses [58, 59]. Intracellular or endosomal PRRs are stimulated by nucleic acids such as single-stranded RNA (ssRNA), and function as detectors of hijacking viral genomes. A restricted number of transcription factors, such as members of the interferon regulatory factor family, AP-1 family members, and NF- $\mathrm{KB}$, initiate transcriptional responses to the recognition of viruses [60]. The initial transcriptional response and consequent interferon signaling result in the generation of antivral effectors.

Clinical and epidemiological studies provide evidence for immune protection by vitamin D against a number of viruses, such as hepatitis viruses, human immunodeficiency virus, and viral respiratory pathogens [61]. Readers are referred to an extensive review by Lee et al. [62] of vitamin $\mathrm{D}$ signaling in anti-viral immunity for responses to non-respiratory viruses. Given that SARS-CoV-2, the etiological agent of COVID-19, primarily affects the lungs, we will consider vitamin D supplementation and viral respiratory tract infections in detail in this review. A meta-analysis of epidemiological data suggests that supplementing with vitamin D daily or weekly decreased the incidence of acute respiratory tract infections, and that the effects were most striking in partipants with the lowest 25D status [63]. In addition, lung epithelial cells, which are responsive to 25 and 1,25D, are the target of most respiratory viruses. Primary human lung epithelial cells express CYP27B1, and, intriguingly, its expression was increased by dsRNA, which mimics viral genomes [64] (Fig. 2). Likewise, $1 \alpha$-hydroxylase activity is enhanced by respiratory syncytial virus (RSV) infection of bronchial epithelial cells [65]. Among the components of $1,25 \mathrm{D}$-mediated antiviral immunity is the strong induction of CAMP gene transcription (Fig. 2). LL37, the active form of CAMP, binds to viral dsRNA, which facilitates its recognition by the PRR TLR3 [66] (Fig. 2). It has been suggested that this mechanism may be an outcome of the capacity of LL37 ability to promote wound healing, as augmented detection of extracellular nucleic acid from dying cells would expedite its clearance [67] (Fig. 2). Recently, LL37 was shown to bind directly to SARS-CoV-2 Spike protein and prevent binding to its receptor ACE2, which likely inhibits its viral entry into host cells [68]. Further, antimicrobial peptides that include LL37, are suggested to play a role in pulmonary defense against viruses by direct binding to and modulating cell-surface receptors, blocking viral replication and binding to virions [69].

Here, we will describe more in depth the molecular evidence for 1,25D-mediated protection against specific respiratory viruses. $1,25 \mathrm{D}$ may directly promote antiviral immunity against the influenza A (InA) virus, a highly contagious pathogen that leads to influenza outbreaks worldwide, mainly during the winter [70]. LL37 can bind directly to InA viruses and, according to electron microscopy data, the
Fig. 2 Antiviral activity of vitamin $\mathrm{D}$ in a lung epithelial cell. Illustration showing events underlying vitamin D metabolism and signaling during viral infection and responses induced by $1,25 \mathrm{D}$. These include induction of CAMP expression as well as $1,25 \mathrm{D}$-mediated suppression of inflammatory cytokines IL-5 and IFN- $\gamma$, ICAM-1, and PAFR. The mature form of CAMP, LL37, binds to viral dsRNA, which enables efficient binding to endosomal TLR3, augmenting TLR3 signaling and subsequent viral clearance. An additional mechanism for viral removal is the induction of autophagy by $1,25 \mathrm{D}$

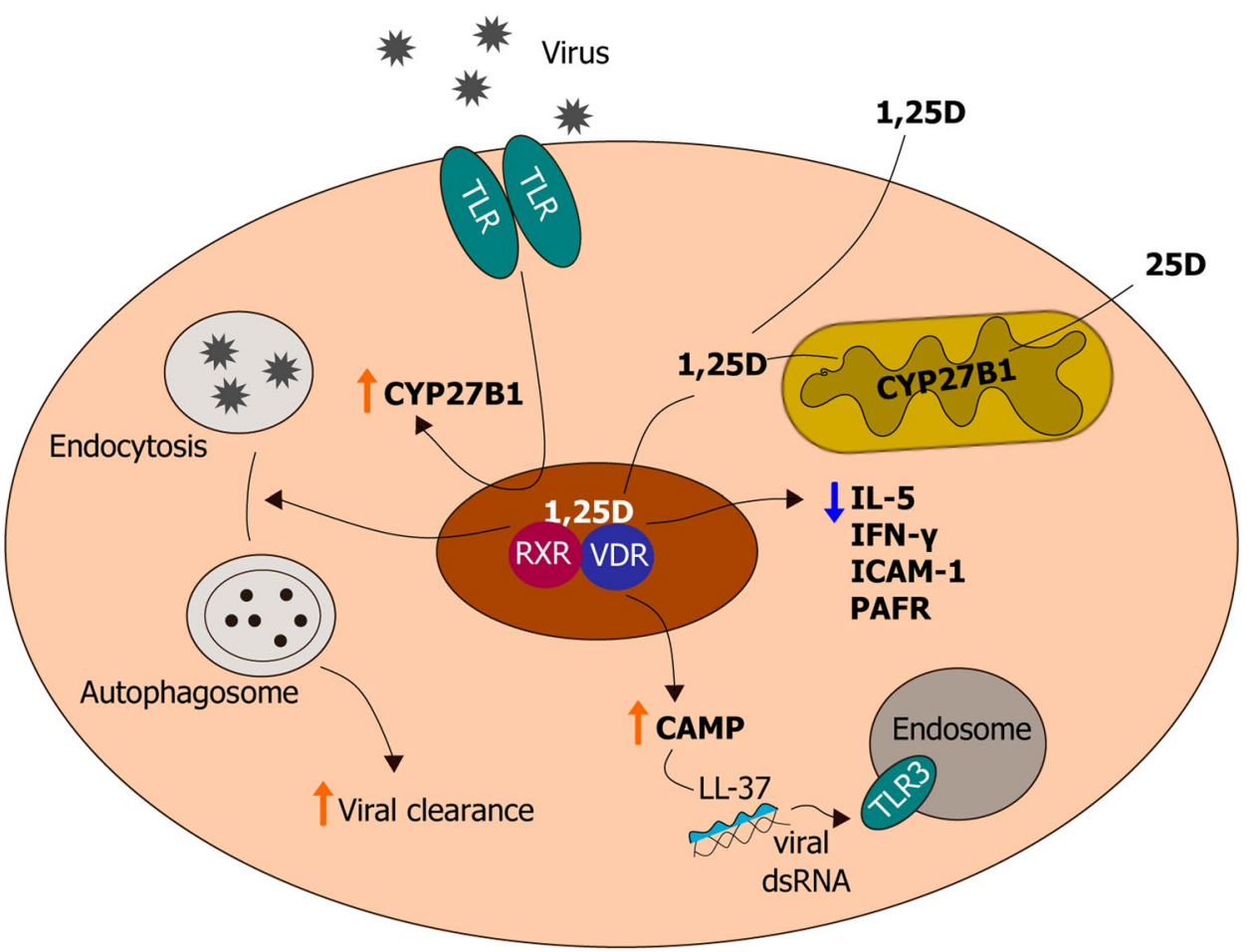


antimicrobial peptide can also disrupt viral membranes [71]. Likewise, the human and murine forms of CAMP decreased InA replication and disease severity in infected mice, in accordance with the above study's findings [72]. Hayashi et al. [73] found that mice fed a diet consisting of a high dose of 25D and infected with the influenza virus exhibited decreased production of the inflammatory cytokines, IL-5 and IFN- $\gamma$ (Fig. 2), as well as reduced virus replication and clinical outcomes of the infection compared to mice that were not supplemented with 25D. Furthermore, in InAinfected human A549 lung epithelial cells, 1,25D restored autophagic flux inhibited by the virus and thereby decrease apoptosis via a VDR-dependent mechanism [74] (Fig. 2). Infection with human RSV, one of the most common viruses to infect children and adults globally, can lead to upper and lower respiractory tract illness and in severe cases may progress to pneumonia, respiratory failure and death [75]. As mentioned above, RSV infection in vitro enhanced $1 \alpha-$ hydroxylase expression (64). In turn, induction by $1,25 \mathrm{D}$ of antimicrobial peptide CAMP expression blocked RSVinduced apoptosis and restricted viral replication in vitro via suppressing assembly of viral particles [76]. One group found no significant effect of $1,25 \mathrm{D}$ was found on rhinovirus (RV) replication in primary human bronchial epithelial cells [77]. However, another study using primary cystic fibrosis bronchial cells, found that $1,25 \mathrm{D}$ dose-dependently suppressed RV load via induction of CAMP [78]. While RV infection decreased expression of the VDR and CYP24A1, treatment of infected cells with 1,25D reduced viral replication and release [65]. Greiller et al. found that treating A549 cells with 25D promoted transient resistance to RV infection [79]. This was attributed to suppression by 25D of $\mathrm{RV}$-induced expression of intercellular adhesion molecule 1 (ICAM-1), a cell surface molecule that functions as the receptor for RVs, and platelet-activating factor receptor (PAFR) [79] (Fig. 2). Most recently, EPs®7630, a herbal drug preparation from the roots of Pelargonium sidoides, which is efficacious against respiratory tract infections, was found to increase host defense against RV by upregulating the VDR in human bronchial epithelial cells [80].

\section{Clinical evidence for vitamin D supplementation and COVID-19: results from a meta-analysis}

Given the numerous accounts attributing an antiviral function for vitamin D signaling, it is appropriate to hypothesize that vitamin D may modulate the effects of the new severe acute respiratory syndrome coronavirus 2 (SARS-CoV-2) that has triggered the COVID-19 pandemic. This concept is elaborated in a number of comprehensive reviews [81, 82]. SARS-CoV-2 infection can be separated into three phases: (i) an asymptomatic phase with or without detectable virus; (ii) a non-critical phase with upper airway pathogenesis; and (iii) a severe, possibly fatal disease characterized by hypoxia, infiltration of 'ground glass' in the lung, and acute respiratory distress syndrome (ARDS), the principal cause of death in COVID-19 [83]. In general, coronaviruses enter cells via endocytosis, and subsequently release their viral RNA into the cytoplasm, produce viral proteins and initiate viral replication/transcription [84]. Although not fully determined, the most likely pattern recognition receptors involved in recognizing SARS-CoV-2 are TLR3 and TLR7 in the endosome, or the cytosolic sensors retinoic acid-inducible gene 1 (RIGI) and melanoma differentiation-associated gene 5 (MDA5), which detect viral RNA [84]. These PRRs are directly linked by signaling cascades to initiate robust interferon responses [84], and an early peak of interferon signaling is followed by a decline in those responses in mild-to moderate COVID19 [85]. However, levels of interferon responses are further increased in severely affected patients, suggesting that they are drivers of COVID pathology [85]. Moreover, numerous studies suggested that COVID-19 infection may be coupled with an inappropriate induction of immune responses which result in a "cytokine storm", an unregulated response to systemic inflammation and secondary organ dysfunction as a consequence of pro-inflammatory cytokine and chemokine production by immune cells [84].

According to a current model, SARS-CoV-2 enters type II pneumocytes and macrophages via recognition of angiotensin converting enzyme 2 (ACE2) receptors, prompting quick virus entry and replication, as well as leading to a down-regulation of these receptors [86]. The reduction of ACE2 receptor activity induces activity of ACE1, thereby leading to the formation of angiotensin II [87]; high levels of angiotensin II may lead to ARDS or cardiopulmonary injury, which occur in severe COVID-19 cases [88]. Futhermore, viral infection results in the production of proinflammatory cytokines such as IL-1, IL-6, CXCL8, and TNF [85, 89, 90]. Increased production of these pro-inflammatory mediators results in an accumulation of inflammatory neutrophils and macrophages in the lungs, further inducing higher proinflammatory cytokine and chemokine production in bronchoalveolar lavage fluid and the circulation [84]. This cytokine storm was especially pronounced in critically ill patients, leading to ARDS, pulmonary edema, epithelial cell apoptosis and multiple organ exhaustion [91]. Futhermore, there is evidence that COVID-19 interferes with the cardiovascular system in hospitalized patients and is associated with conditions such as myocardial injury, acute coronary syndromes, arrthymias and thrombotic complications [82].

Epidemiological evidence and ecological studies suggest that vitamin D supplementation may be of therapeutic benefit in alleviating symptoms associated with COVID-19. For instance, there are several associations reported between 
COVID-19 and sun exposure [92]. An ecological study correlated low sun exposure, using proximity to the equator to estimate average exposure levels, with higher COVID-19 mortality in 88 countries [93]. This is further supported by observational studies regarding a higher number of deaths due to COVID-19 among individuals with darker skin [94, 95]. In addition, amid the elderly population, increased COVID-19 mortality was described to be linked with preexisting, age-associated immune dysregulation coupled with vitamin D deficiency [96].

Mechanistically, 1,25D inhibits TNF/NFkB and IFN- $\gamma$ signaling pathways [82], as well as decreasing the production of pro-inflammatory cytokines such as IL-6, which contribute to the cytokine storm phenomenon [97]. In addition, animal models of ARDS provide evidence that $1,25 \mathrm{D}$ can mitigate LPS-initiated increased lung permeability by regulating activity of the renin-angiotensin-aldosterone (RAA) system and increasing expression of ACE2 [98]. This is supported by studies in CYP27b1-/- or Vdr-/- mouse models, which develop myocardial hypertrophies, with overexpression of components of the RAA system, hypertension and atherosclerosis [99, 100]. Moreover, vitamin D is a potent inhibitor of renin, a proteolytic enzyme that induces expression of angiotensin II, which as mentioned above, promotes increased COVID-19 severity [87]. The inhibition of renin by vitamin D was first demonstrated by a 2004 study, where vitamin D-deficient mice exhibited increased renin expression, whereas $1,25 \mathrm{D}$ injection suppressed renin synthesis in the mice [101]. The investigators also validated this finding in As4.1 cells, a murine renin-expressing cell line, in which $1,25 \mathrm{D}$ was found to directly attenuate renin gene transcription by a VDR-dependent mechanism [101]. Furthermore, cathelicidin, the antimicrobial peptide robustly induced by $1,25 \mathrm{D}$, was shown to suppress hyperoxia-induced lung injury in newborn rats [102]. A number of meta-analyses of clinical studies support the preclinical data, as they link low
25D levels to heightened risk of cardiovascular outcomes, and ensuing mortality [48, 103-106]. COVID-19 is also associated with increased risk of coagulopathies and thrombosis [107]. In this regard, there are clinical reports linking poor vitamin D status to increased thrombotic events [108, 109]. A summary of the characteristics of COVID-19 pathogenesis and the effects of vitamin $\mathrm{D}$ is provided in Table 1.

There is ample and growing clinical data exploring the association between vitamin D levels and COVID-19 pathogenesis. A meta-analysis by Kazemi and researchers surveyed 39 retrospective and prospective cohort, crosssectional, case-control, and randomized controlled trial studies (up to November 26, 2020) to assess the relation between 25D status and SARS-CoV-2 infection as well as COVID-19 severity [110]. In reports that were adjusted and nonadjusted for confounders, the researchers found a greater risk of SARS-CoV-2 infection in the vitamin D deficient group. There were two compelling studies in this regard. An ecological study including 20 European countries concluded negative correlations between mean levels of vitamin $\mathrm{D}$ and COVID-19 infection and mortality rates [111]. Similarily, a cross-sectional study among 392 healthcare workers from the United Kingdom (UK) reported that vitamin D deficiency is an independent risk factor for COVID-19 seroconversion [112], a time period during which a specific antibody is detected in the blood in response to a virus [113]. Furthermore, in the studies that evaluated a link between vitamin D insufficiency and disease severity, most suggested such an association [110]. Among those reports were three randomized controlled trials (RCTs), the first of which was a pilot study performed by Castillo and co-workers at a university hospital in Cordoba, Spain [114]. Castillo et al. observed that only 1 out of 50 patients that supplemented with oral 25D required intensive care unit (ICU) admission, in comparison to the 13 out of 26 untreated counterpart that were admitted. While the results appear compelling, the

Table 1 Summary of the symptoms contributing to COVID-19 pathogenesis and evidence for how vitamin D may be effective in combatting them

\begin{tabular}{lc}
\hline Features of COVID-19 pathogenesis & Effect of vitamin D on COVID-19 \\
\hline $\begin{array}{l}\text { 1. Angiotensin II and the renin-angiotensin system } \\
\text { SARS-CoV-2 binds to ACE2 on alveolar cells [86] and impairs ratio } \\
\text { of ACE2/ACE activity, which as a consequence, increases angioten- } \\
\text { sin II [88] }\end{array}$ & $\begin{array}{c}\text { Increases ACE2 expression (98) and inhibits renin [101], both of which } \\
\text { reduce angiotensin II levels }\end{array}$ \\
$\begin{array}{l}\text { 2. Inflammatory cytokine storm } \\
\text { Increases production of pro-inflammatory cytokines leading to a }\end{array}$ & $\begin{array}{c}\text { Decreases production of pro-inflammatory cytokines (e.g. IL-6) that } \\
\text { contribute to cytokine storm [97] }\end{array}$ \\
$\begin{array}{l}\text { 3. Cardiopulmonary injury } \\
\text { Severe COVID-19 cases result in ARDS, pulmonary edema, cardio- } \\
\text { vascular injury, coagulopathies [82, 91], and thrombotic events [107] }\end{array}$ & $\begin{array}{c}\text { Poor vitamin D status is associated with increased risk of cardiovascular } \\
\text { outcomes and thrombosis [48, 103-106] } \\
1,25 \mathrm{D} \text { promotes production of cathelicidin, which can attenuate lung } \\
\text { injury in a rat model of hyperoxia (102) }\end{array}$ \\
\hline
\end{tabular}


study has been critized for being poorly controlled [114]. A subsequent RCT conducted in India validated the findings from the earlier Spanish study; high-dose oral vitamin $\mathrm{D}_{3}$ supplementation (60,000 IU per day for at least 7 days) in asymptomatic or mildly symptomatic SARS-CoV-2 RNA positive vitamin $D$ deficient participants resulted in significantly enhanced SARS-CoV-2 viral clearance and decreased amounts of fibrinogen, an inflammatory marker associated with COVID-19 [115]. However, data from a multicenter, double-blind, randomized, placebo-controlled trial conducted in two centers in Sao Paulo, Brazil did not agree with the previous two trials [116]. One dose of 200,000 IU of vitamin $\mathrm{D}_{3}$ supplementation did not significantly attenuate length of hospital stay or other clinical outcomes, such as requirement for mechanical ventilation, compared with the placebo control group, as determined by the Brazilian RCT [116]. A limitation of this study, however, is that supplementation with vitamin $\mathrm{D}_{3}$ of their mostly obese population of patients (mean body mass index $31.6 \mathrm{~kg} / \mathrm{m} 2$ ) may have been administered too late to considerably influence clinically relevant outcomes, as randomization occurred approximately 10 days following emergence of symptoms [117]. In addition, vitamin $\mathrm{D}_{3}$ supplementation is less efficacious at increasing serum 25D concentrations than 25D itself [117]. The final conclusion from Kazemi et al.'s meta-analysis, is that for studies that assessed a relationship between vitamin D insufficiency and ICU admission, pulmonary complications, hospitalization, and inflammation, results were inconsistent [110].

\section{Recent clinical data assessing an association between vitamin $D$ and COVID-19 infection and course of disease}

Since late 2020, there have been several studies published with the aim of determining whether supplementation with vitamin D can curb COVID-19 infection. A case-control study conducted over two months with 201 hospitalized patients and 201 matched controls from Iran described an inverse association between circulating 25D levels and COVID-19 infection [118]. Furthermore, in their singlecenter retrospective cohort study, Meltzer et al. found an increased risk for COVID-19 susceptibility among black individuals with $25 \mathrm{D}$ levels less than $40 \mathrm{ng} / \mathrm{mL}(100 \mathrm{nM})$ in comparison with those with $40 \mathrm{ng} / \mathrm{mL}(100 \mathrm{nM})$ or greater [119]. However, no significant associations were observed for white participants [119]. A retrospective case-control investigation in Saudi Arabia determined that, although low vitamin D levels may raise the risk for mortality, they are not linked to increased risk of SARS-CoV-2 infection [120]. Moreover, researchers at McGill University were concerned with vitamin $\mathrm{D}$ levels being associated with many confounding variables, such as age, sex and ethnicity, and hence there may not be a causal association with vitamin D and COVID19 protection [121]. To circumvent this, the investigators obtained genetic variants from 443,734 individuals of European ancestry and used these for Mendelian randomization, a genetic tool to limit the confounding, to approximate the influence of increased vitamin D on COVID-19 outcomes. From this, they could not find evidence for a link between genetically estimated circulating 25D levels and COVID-19 infection, hospitalization, or severe disease. However, it is important to note that the combined effect of all variants that tend to lower 25D levels is only about 5\% [121]. Further, a hospital-based cross-sectional investigation in India observed a prevalence of $59 \%$ and $89 \%$ of vitamin D deficiency and insufficiency, respectively, among 156 COVID19 hospitalized patients [122].

An equally important goal is to determine vitamin D supplementation can prevent critical course of disease and death from infection by COVID-19. To this end, a large UK-based cross-sectional observational study recruited 986 COVID-19 patients from three different hospitals, 151 of who received 280,000 IU of vitamin $\mathrm{D}_{3}$, given either as separate weekly or daily doses over a time period of up to seven weeks [123]. This booster therapy of vitamin D led to a markedly decreased risk of COVID-19 mortality among those afflicted with the disease [123]. Consistent with this report, a cohort investigation of 30 ICU patients in Greece, as well as a correlation study from 157 residents of an Italian nursing home revealed reduced mortality from SARS-CoV-2 infection with vitamin $D$ treatment $[124,125]$. A retrospective chart review report conducted over five months at Boston University Medical Center also found similar results; an independent association between serum 25D $30 \mathrm{ng} /$ $\mathrm{mL}(75 \mathrm{nM})$ or greater and reduced risk of mortality from COVID-19 in elderly and non-obese patients was described [126]. Additional support for this association is provided by an Italian prospective study, which noted significantly lower 25D levels in severely symptomatic COVID-19 patients, as well as those who died from the disease [127]. The investigators also found an inverse correlation between low 25D status and high levels of the pro-inflammatory cytokine, IL-6 [127]. Furthermore, 25D insufficiency was related to increased severity of lung consolidation, which occurs when air that fills the lungs is replaced with bodily liquid, longer duration of disease and risk of death in an elderly population with COVID-19 compared with age-matched control subjects [128]. Although 25D status was not correlated with changes in clinical course, low levels of $1,25 \mathrm{D}$ were linked with prolonged mechanical ventilation and a worse acute physiology and chronic health evaluation score in 26 patients receiving intensive care with confirmed SARS-CoV-2 infection and COVID-19 induced acute respiratory distress 
syndrome [129]. In a retrospective study conducted in Sicily, low levels of vitamin $\mathrm{D}$ were observed in 50 hospital patients with a positive polymerase chain reaction (PCR) for SARSCoV-2 [130]. Despite this finding, an association could not be found between low vitamin D status and increased markers of inflammation or clinical severity [130]. In addition, a meta-analysis of 31 observational studies found a trend between serum 25D levels of less than $20 \mathrm{ng} / \mathrm{ml}(50 \mathrm{nM})$ and an increased risk of mortality, ICU admission and ventilation; however, these associations were not found to be statistically significant [131]. Nevertheless, another meta-analysis that included 47 countries from Europe and Asia, revealed a significant positive correlation between both COVID-19 infection and mortality rates and vitamin D deficiency [132].

\section{Ongoing trials of vitamin D and COVID-19}

At the time of this writing, there are 54 ongoing clinical trials registered (www.clinicaltrials.gov) assessing links between vitamin D and COVID-19. Here, we will discuss a few of these current trials. VIVID (vitamin D for COVID-19) trial is cluster randomized, double-blinded trial that will test vitamin $\mathrm{D}_{3}$ supplementation for early treatment and post-exposure prevention of COVID-19 using 2700 participants in the US [133]. The proposed time frame of the study is 4 weeks and it is estimated to be completed on December 31, 2021 [133]. Another ambitious project is the CORONAVIT trial, a randomised clinical trial in the UK, to be completed by June 30, 2021, that will recruit 6200 residents 16 years of age or older to assess whether a "test-and-treat" approach to correct vitamin D deficient individuals will lead to a reduced risk and/or severity of COVID-19 [134]. Investigators will offer participants in the intervention group with $25 \mathrm{D}$ level $<30 \mathrm{ng} / \mathrm{mL}(75 \mathrm{nM})$ a daily low dose of $800 \mathrm{IU}$ or a higher dose of $3200 \mathrm{IU}$ vitamin $D_{3}$, whereas those in the control group will receive the national recommendation of $400 \mathrm{IU}$ per day of vitamin $\mathrm{D}$ for a period of 6 months [134]. Furthermore, the COVIDIOL trial in Cordoba, Spain follows the pilot study mentioned above with 76 participants [114], and will include an estimated 1008 patients aged 18-90 years with COVID-19 and a radiological image showing inflammatory pleuropulmonary exudate [135]. The intervention group will obtain the best available treatment plus oral $25 \mathrm{D}(0.532 \mathrm{mg}=21,280 \mathrm{IU}$ on day 1 , $0.266 \mathrm{mg}=10.640 \mathrm{IU}$ on days $3,7,14,21$ and 28 ), whereas the control group is given only the best available treatment [135]. The trial will last 28 days in total and its end date is June 30, 2021 [135]. In addition, a high-single dose of vitamin D randomized double-blind clinical trial in Switzerland will be conducted with vitamin D-deficient COVID-19 patients aged 18 years or older [136]. The intervention group will receive a single oral high dose of $140000 \mathrm{IU}$ of vitamin $\mathrm{D}_{3}$ as well as continue with the standard dose of 800 IU daily, whereas the control counterpart will obtain one dose of placebo orally and also continue with the $800 \mathrm{IU}$ dose per day. The study intends to recruit 80 patients and its estimated completion date is June 30, 2021 [136].

\section{Conclusions}

There is growing evidence that vitamin D signaling is active throughout the immune system, and that it is physiologically important in protecting the human host from bacterial and viral invaders. Mechanisms of vitamin D-innate immune signaling include its production of cytokines, antimicrobial proteins, and pattern recognition receptors. Early laboratory studies showing that $1,25 \mathrm{D}$ stimulated antibacterial innate immunity are supported by increasing clinical evidence for the beneficial effects of vitamin D supplementation in bacterial infections. The actions of vitamin $D$ in the immune system have also raised the possibility that vitamin D supplementation may combat viral infections, including those caused by SARS-CoV-2. There is evidence from several preclinical and clinical studies that vitamin D supplementation can attenuate viral respiratory tract infections. Vitamin D deficiency is common in most North American and European countries [137, 138], and is particularly prevalent in nursing homes $[139,140]$, which have been hard-hit by the COVID-19 pandemic. Many clinical reports suggest that vitamin D supplementation, at least for the elderly and patients with low 25D status, can help in protecting against COVID-19 infection and severe course of disease. However, globally, the clinical data for the beneficial therapeutic effects of vitamin D supplementation in COVID-19 is mixed, and it is clear that more research on the possible role of vitamin $\mathrm{D}$ in influencing the risk and course of COVID-19 disease is required.

Funding Grant support: Canadian Institutes of Health Research.

\section{Declarations}

Conflict of interest The authors have declared that no conflict of interest exists.

Open Access This article is licensed under a Creative Commons Attribution 4.0 International License, which permits use, sharing, adaptation, distribution and reproduction in any medium or format, as long as you give appropriate credit to the original author(s) and the source, provide a link to the Creative Commons licence, and indicate if changes were made. The images or other third party material in this article are included in the article's Creative Commons licence, unless indicated otherwise in a credit line to the material. If material is not included in the article's Creative Commons licence and your intended use is not permitted by statutory regulation or exceeds the permitted use, you will need to obtain permission directly from the copyright holder. To view a copy of this licence, visit http://creativecommons.org/licenses/by/4.0/. 


\section{References:}

1. Tavera-Mendoza LE, White JH. Cell defenses and the sunshine vitamin. Sci Am. 2007;297(5):62-5, 8-70, 2.

2. Tanaka Y, Deluca HF. Role of 1,25-dihydroxyvitamin D3 in maintaining serum phosphorus and curing rickets. Proc Natl Acad Sci U S A. 1974;71(4):1040-4.

3. Pettifor JM, Thandrayen K, Thacher TD. Chapter 67 - Vitamin D Deficiency and Nutritional Rickets in Children. In: Feldman D, editor. Vitamin D (Fourth Edition): Academic Press; 2018. p. 179-201.

4. Gonzalez-Gross M, Valtuena J, Breidenassel C, Moreno LA, Ferrari M, Kersting M, et al. Vitamin D status among adolescents in Europe: the Healthy Lifestyle in Europe by Nutrition in Adolescence study. Br J Nutr. 2012;107(5):755-64.

5. Diethelm K, Huybrechts I, Moreno L, De Henauw S, Manios Y, Beghin L, et al. Nutrient intake of European adolescents: results of the HELENA (Healthy Lifestyle in Europe by Nutrition in Adolescence) Study. Public Health Nutr. 2014;17(3):486-97.

6. Cashman KD, Dowling KG, Skrabakova Z, Gonzalez-Gross M, Valtuena J, De Henauw S, et al. Vitamin D deficiency in Europe: pandemic? Am J Clin Nutr. 2016;103(4):1033-44.

7. Kamboj P, Dwivedi S, Toteja GS. Prevalence of hypovitaminosis D in India \& way forward. Indian J Med Res. 2018;148(5):548-56.

8. Hollis BW. Assessment of vitamin D status and definition of a normal circulating range of 25-hydroxyvitamin D. Curr Opin Endocrinol Diabetes Obes. 2008;15(6):489-94.

9. Cheng JB, Levine MA, Bell NH, Mangelsdorf DJ, Russell DW. Genetic evidence that the human CYP2R1 enzyme is a key vitamin D 25-hydroxylase. Proc Natl Acad Sci U S A. 2004;101(20):7711-5.

10. Zhu JG, Ochalek JT, Kaufmann M, Jones G, Deluca HF. CYP2R1 is a major, but not exclusive, contributor to 25-hydroxyvitamin D production in vivo. Proc Natl Acad Sci U S A. 2013;110(39):15650-5.

11. Zehnder D, Bland R, Williams MC, McNinch RW, Howie AJ, Stewart PM, et al. Extrarenal expression of 25-hydroxyvitamin d(3)-1 alpha-hydroxylase. J Clin Endocrinol Metab. 2001;86(2):888-94.

12. Hewison M, Burke F, Evans KN, Lammas DA, Sansom DM, Liu P, et al. Extra-renal 25-hydroxyvitamin D3-1 $\alpha$-hydroxylase in human health and disease. J Steroid Biochem Mol Biol. 2007;103(3-5):316-21.

13. Bikle DD. Vitamin D metabolism, mechanism of action, and clinical applications. Chem Biol. 2014;21(3):319-29.

14. Wang TT, Tavera-Mendoza LE, Laperriere D, Libby E, MacLeod NB, Nagai Y, et al. Large-scale in silico and microarray-based identification of direct 1,25-dihydroxyvitamin D3 target genes. Mol Endocrinol. 2005;19(11):2685-95.

15. Erben RG, Soegiarto DW, Weber K, Zeitz U, Lieberherr M, Gniadecki $\mathrm{R}$, et al. Deletion of deoxyribonucleic acid binding domain of the vitamin $\mathrm{D}$ receptor abrogates genomic and nongenomic functions of vitamin D. Mol Endocrinol. 2002;16(7):1524-37.

16. Overbergh L, Decallonne B, Valckx D, Verstuyf A, Depovere $\mathrm{J}$, Laureys $\mathrm{J}$, et al. Identification and immune regulation of 25-hydroxyvitamin D-1-alpha-hydroxylase in murine macrophages. Clin Exp Immunol. 2000;120(1):139-46.

17. Liu PT, Stenger S, Li H, Wenzel L, Tan BH, Krutzik SR, et al. Toll-like receptor triggering of a vitamin D-mediated human antimicrobial response. Science. 2006;311(5768):1770-3.

18. Fischer S. Pattern Recognition Receptors and Control of Innate Immunity: Role of Nucleic Acids. Curr Pharm Biotechnol. 2018;19(15):1203-9.
19. Adams JS, Gacad MA. Characterization of 1 alpha-hydroxylation of vitamin D3 sterols by cultured alveolar macrophages from patients with sarcoidosis. J Exp Med. 1985;161(4):755-65.

20. Adams JS, Rafison B, Witzel S, Reyes RE, Shieh A, Chun R, et al. Regulation of the extrarenal CYP27B1-hydroxylase. J Steroid Biochem Mol Biol. 2014;144 Pt A:22-7.

21. Oberg F, Botling J, Nilsson K. Functional antagonism between vitamin D3 and retinoic acid in the regulation of CD14 and CD23 expression during monocytic differentiation of U-937 cells. $\mathbf{J}$ Immunol. 1993;150(8 Pt 1):3487-95.

22. Schauber J, Dorschner RA, Coda AB, Buchau AS, Liu PT, Kiken $\mathrm{D}$, et al. Injury enhances TLR2 function and antimicrobial peptide expression through a vitamin D-dependent mechanism. J Clin Invest. 2007;117(3):803-11.

23. Arboleda Alzate JF, Rodenhuis-Zybert IA, Hernandez JC, Smit JM, Urcuqui-Inchima S. Human macrophages differentiated in the presence of vitamin D3 restrict dengue virus infection and innate responses by downregulating mannose receptor expression. PLoS Negl Trop Dis. 2017;11(10):e0005904.

24. Wang TT, Nestel FP, Bourdeau V, Nagai Y, Wang Q, Liao $\mathrm{J}$, et al. Cutting edge: 1,25-dihydroxyvitamin D3 is a direct inducer of antimicrobial peptide gene expression. J Immunol. 2004;173(5):2909-12.

25. Gutierrez MG, Master SS, Singh SB, Taylor GA, Colombo MI, Deretic V. Autophagy is a defense mechanism inhibiting BCG and Mycobacterium tuberculosis survival in infected macrophages. Cell. 2004;119(6):753-66.

26. Deretic V. Autophagy in leukocytes and other cells: mechanisms, subsystem organization, selectivity, and links to innate immunity. J Leukoc Biol. 2016;100(5):969-78.

27. Dimitrov V, Barbier C, Ismailova A, Wang Y, Dmowski K, Salehi-Tabar R, et al. Vitamin D-regulated gene expression profiles: Species-specificity and cell-specific effects on metabolism and immunity. Endocrinology. 2021;162(2):bqaa218.

28. Gombart AF, Borregaard N, Koeffler HP. Human cathelicidin antimicrobial peptide (CAMP) gene is a direct target of the vitamin $\mathrm{D}$ receptor and is strongly up-regulated in myeloid cells by 1,25-dihydroxyvitamin D3. FASEB J. 2005;19(9):1067-77.

29. Dimitrov V, White JH. Species-specific regulation of innate immunity by vitamin D signaling. J Steroid Biochem Mol Biol. 2016;164:246-53.

30. Wang TT, Dabbas B, Laperriere D, Bitton AJ, Soualhine H, Tavera-Mendoza LE, et al. Direct and indirect induction by 1,25-dihydroxyvitamin D3 of the NOD2/CARD15-defensin beta2 innate immune pathway defective in Crohn disease. J Biol Chem. 2010;285(4):2227-31.

31. Cuthbert AP, Fisher SA, Mirza MM, King K, Hampe J, Croucher $\mathrm{PJ}$, et al. The contribution of NOD2 gene mutations to the risk and site of disease in inflammatory bowel disease. Gastroenterology. 2002;122(4):867-74.

32. Coulombe F, Divangahi M, Veyrier F, de Leseleuc L, Gleason JL, Yang Y, et al. Increased NOD2-mediated recognition of N-glycolyl muramyl dipeptide. J Exp Med. 2009;206(8):1709-16.

33. Verway M, Bouttier M, Wang TT, Carrier M, Calderon M, An BS, et al. Vitamin D induces interleukin-1beta expression: paracrine macrophage epithelial signaling controls M. tuberculosis infection. PLoS Pathog. 2013;9(6):e1003407.

34. Khoo AL, Chai LY, Koenen HJ, Oosting M, Steinmeyer A, Zuegel U, et al. Vitamin $\mathrm{D}(3)$ down-regulates proinflammatory cytokine response to Mycobacterium tuberculosis through pattern recognition receptors while inducing protective cathelicidin production. Cytokine. 2011;55(2):294-300.

35. Di Rosa M, Malaguarnera G, De Gregorio C, Palumbo M, Nunnari $\mathrm{G}$, Malaguarnera L. Immuno-modulatory effects of vitamin D3 in human monocyte and macrophages. Cell Immunol. 2012;280(1):36-43. 
36. Zhang Y, Leung DY, Richers BN, Liu Y, Remigio LK, Riches DW, et al. Vitamin D inhibits monocyte/macrophage proinflammatory cytokine production by targeting MAPK phosphatase-1. J Immunol. 2012;188(5):2127-35.

37. Takahashi K, Nakayama Y, Horiuchi H, Ohta T, Komoriya K, Ohmori $\mathrm{H}$, et al. Human neutrophils express messenger RNA of vitamin $\mathrm{D}$ receptor and respond to 1alpha,25-dihydroxyvitamin D3. Immunopharmacol Immunotoxicol. 2002;24(3):335-47.

38. Agerberth B, Charo J, Werr J, Olsson B, Idali F, Lindbom L, et al. The human antimicrobial and chemotactic peptides LL-37 and alpha-defensins are expressed by specific lymphocyte and monocyte populations. Blood. 2000;96(9):3086-93.

39. Yip KH, Kolesnikoff N, Yu C, Hauschild N, Taing H, Biggs $\mathrm{L}$, et al. Mechanisms of vitamin $\mathrm{D}(3)$ metabolite repression of IgE-dependent mast cell activation. J Allergy Clin Immunol. 2014;133(5):1356-64, 64 e1-14.

40. Kitajima I, Maruyama I, Matsubara H, Osame M, Igata A. Immune dysfunction in hypophosphatemic vitamin D-resistant rickets: immunoregulatory reaction of 1 alpha $(\mathrm{OH})$ vitamin $\mathrm{D} 3$. Clin Immunol Immunopathol. 1989;53(1):24-31.

41. Quesada JM, Serrano I, Borrego F, Martin A, Pena J, Solana R. Calcitriol effect on natural killer cells from hemodialyzed and normal subjects. Calcif Tissue Int. 1995;56(2):113-7.

42. Deniz G, Erten G, Kucuksezer UC, Kocacik D, Karagiannidis C, Aktas E, et al. Regulatory NK cells suppress antigen-specific T cell responses. J Immunol. 2008;180(2):850-7.

43. Quesada JM, Solana R, Martin A, Santamaria M, Serrano I, Martinez ME, et al. The effect of calcitriol on natural killer cell activity in hemodialyzed patients. J Steroid Biochem. 1989;34(1-6):423-5.

44. Vargas Buonfiglio LG, Cano M, Pezzulo AA, Vanegas Calderon OG, Zabner J, Gerke AK, et al. Effect of vitamin D3 on the antimicrobial activity of human airway surface liquid: preliminary results of a randomised placebo-controlled double-blind trial. BMJ Open Respir Res. 2017;4(1):e000211.

45. Gyll J, Ridell K, Ohlund I, Karlsland Akeson P, Johansson I, Lif HP. Vitamin D status and dental caries in healthy Swedish children. Nutr J. 2018;17(1):11.

46. Olczak-Kowalczyk D, Kaczmarek U, Gozdowski D, TurskaSzybka A. Association of parental-reported vitamin D supplementation with dental caries of 3-year-old children in Poland: a cross-sectional study. Clinical Oral Investigations. 2021:1-12.

47. Yoshida K, Suzuki S, Kawada-Matsuo M, Nakanishi J, HirataTsuchiya S, Komatsuzawa H, et al. Heparin-LL37 complexes are less cytotoxic for human dental pulp cells and have undiminished antimicrobial and LPS-neutralizing abilities. Int Endod J. 2019;52(9):1327-43.

48. Theodoratou E, Tzoulaki I, Zgaga L, Ioannidis JP. Vitamin D and multiple health outcomes: umbrella review of systematic reviews and meta-analyses of observational studies and randomised trials. BMJ. 2014;348:g2035.

49. Hujoel PP. Vitamin D and dental caries in controlled clinical trials: systematic review and meta-analysis. Nutr Rev. 2013;71(2):88-97.

50. White JH. Vitamin D deficiency and the pathogenesis of Crohn's disease. J Steroid Biochem Mol Biol. 2018;175:23-8.

51. Li J, Chen N, Wang D, Zhang J, Gong X. Efficacy of vitamin D in treatment of inflammatory bowel disease: A meta-analysis. Medicine (Baltimore). 2018;97(46):e12662.

52. Gubatan J, Chou ND, Nielsen OH, Moss AC. Systematic review with meta-analysis: association of vitamin D status with clinical outcomes in adult patients with inflammatory bowel disease. Aliment Pharmacol Ther. 2019;50(11-12):1146-58.

53. Yang Y, Cui X, Li J, Wang H, Li Y, Chen Y, et al. Clinical evaluation of vitamin D status and its relationship with disease activity and changes of intestinal immune function in patients with Crohn's disease in the Chinese population. Scand J Gastroenterol. 2021;56(1):20-9.

54. Ham NS, Hwang SW, Oh EH, Kim J, Lee HS, Park SH, et al. Influence of Severe Vitamin D Deficiency on the Clinical Course of Inflammatory Bowel Disease. Dig Dis Sci. 2021;66(2):587-96.

55. Lee GH, Kim CG, Kim JS, Jung HC, Song IS. Frequency analysis of NOD2 gene mutations in Korean patients with Crohn's disease. Korean J Gastroenterol. 2005;45(3):162-8.

56. Yamada A, Komaki Y, Komaki F, Haider H, Micic D, Pekow J, et al. The Correlation between Vitamin D Levels and the Risk of Postoperative Recurrence in Crohn's Disease. Digestion. 2021:1-9.

57. Fletcher J, Swift A, Hewison M, Cooper SC. Screening and Treatment of Vitamin D Deficiency in UK Patients with Crohn's Disease: Self-Reported Practice among Gastroenterologists. Nutrients. 2020;12(4).

58. Kawasaki T, Kawai T. Toll-like receptor signaling pathways Front Immunol. 2014;5:461.

59. Chow KT, Gale M Jr, Loo YM. RIG-I and Other RNA Sensors in Antiviral Immunity. Annu Rev Immunol. 2018;36:667-94.

60. Tripathi S, Garcia-Sastre A. Antiviral innate immunity through the lens of systems biology. Virus Res. 2016;218:10-7.

61. Lee C. Controversial Effects of Vitamin D and Related Genes on Viral Infections, Pathogenesis, and Treatment Outcomes. Nutrients. 2020;12(4).

62. Lee C. Controversial effects of vitamin D and related genes on viral infections, pathogenesis, and treatment outcomes. Nutrients. 2020;12(4):962.

63. Martineau AR, Jolliffe DA, Hooper RL, Greenberg L, Aloia JF, Bergman P, et al. Vitamin D supplementation to prevent acute respiratory tract infections: systematic review and metaanalysis of individual participant data. BMJ. 2017;356:i6583.

64. Hansdottir S, Monick MM, Hinde SL, Lovan N, Look DC, Hunninghake GW. Respiratory epithelial cells convert inactive vitamin D to its active form: potential effects on host defense. J Immunol. 2008;181(10):7090-9.

65. Telcian AG, Zdrenghea MT, Edwards MR, Laza-Stanca V, Mallia P, Johnston SL, et al. Vitamin D increases the antiviral activity of bronchial epithelial cells in vitro. Antiviral Res. 2017;137:93-101.

66. Singh D, Vaughan R, Kao CC. LL-37 peptide enhancement of signal transduction by Toll-like receptor 3 is regulated by $\mathrm{pH}$ : identification of a peptide antagonist of LL-37. J Biol Chem. 2014;289(40):27614-24.

67. Scheenstra MR, van Harten RM, Veldhuizen EJA, Haagsman HP, Coorens M. Cathelicidins Modulate TLR-Activation and Inflammation. Front Immunol. 2020;11:1137.

68. Roth A, Luetke S, Meinberger D, Hermes G, Sengle G, Koch M, et al. LL-37 fights SARS-CoV-2: The Vitamin D-Inducible Peptide LL-37 Inhibits Binding of SARS-CoV-2 Spike Protein to its Cellular Receptor Angiotensin Converting Enzyme 2 In Vitro. bioRxiv. 2020.

69. Ghosh SK, Weinberg A. Ramping Up Antimicrobial Peptides Against Severe Acute Respiratory Syndrome Coronavirus-2. Frontiers in Molecular Biosciences. 2021;8.

70. Moghadami M. A narrative review of influenza: a seasonal and pandemic disease. Iran J Med Sci. 2017;42(1):2.

71. Tripathi S, Tecle T, Verma A, Crouch E, White M, Hartshorn KL. The human cathelicidin LL-37 inhibits influenza A viruses through a mechanism distinct from that of surfactant protein D or defensins. J Gen Virol. 2013;94(Pt 1):40.

72. Barlow PG, Svoboda P, Mackellar A, Nash AA, York IA, Pohl $\mathrm{J}$, et al. Antiviral activity and increased host defense against influenza infection elicited by the human cathelicidin LL-37. PloS one. 2011;6(10):e25333. 
73. Hayashi H, Okamatsu M, Ogasawara H, Tsugawa N, Isoda $\mathrm{N}$, Matsuno K, et al. Oral Supplementation of the Vitamin D Metabolite $25(\mathrm{OH})$ D3 Against Influenza Virus Infection in Mice. Nutrients. 2020;12(7):2000.

74. Godbole NM, Sinha RA, Tiwari S, Pawar SD, Dhole T. Analysis of influenza virus-induced perturbation in autophagic flux and its modulation during Vitamin D3 mediated anti-apoptotic signaling. Virus research. 2020;282:197936.

75. Meng J, Stobart CC, Hotard AL, Moore ML. An overview of respiratory syncytial virus. PLoS Pathog. 2014;10(4):e1004016.

76. Currie SM, Findlay EG, McHugh BJ, Mackellar A, Man T, Macmillan D, et al. The human cathelicidin LL-37 has antiviral activity against respiratory syncytial virus. PloS one. 2013;8(8):e73659.

77. Brockman-Schneider RA, Pickles RJ, Gern JE. Effects of vitamin $\mathrm{D}$ on airway epithelial cell morphology and rhinovirus replication. PloS one. 2014;9(1):e86755.

78. Schögler A, Muster RJ, Kieninger E, Casaulta C, Tapparel C, Jung A, et al. Vitamin D represses rhinovirus replication in cystic fibrosis cells by inducing LL-37. Eur Respir J. 2016;47(2):520-30.

79. Greiller CL, Suri R, Jolliffe DA, Kebadze T, Hirsman AG, Griffiths $\mathrm{CJ}$, et al. Vitamin D attenuates rhinovirus-induced expression of intercellular adhesion molecule-1 (ICAM-1) and platelet-activating factor receptor (PAFR) in respiratory epithelial cells. J Steroid Biochem Mol Biol. 2019;187:152-9.

80. Roth M, Sun Q, Tamm M. Up-Regulated Vitamin D Receptor by Pelargonium sidoides Extract EPs® 7630 Contributes to Rhinovirus Defense in Bronchial Epithelial Cells. Pharmaceuticals. 2021;14(2):172.

81. Lisco G, De Tullio A, Stragapede A, Solimando AG, Albanese F, Capobianco M, et al. COVID-19 and the Endocrine System: A Comprehensive Review on the Theme. J Clin Med. 2021;10(13):2920.

82. Bilezikian JP, Bikle D, Hewison M, Lazaretti-Castro M, Formenti AM, Gupta A, et al. Mechanisms in endocrinology: vitamin D and COVID-19. Eur J Endocrinol. 2020;183(5):R133-47.

83. Nile SH, Nile A, Qiu J, Li L, Jia X, Kai G. COVID-19: Pathogenesis, cytokine storm and therapeutic potential of interferons. Cytokine Growth Factor Rev. 2020;53:66-70.

84. Schultze JL, Aschenbrenner AC. COVID-19 and the human innate immune system. Cell. 2021.

85. Lucas C, Wong P, Klein J, Castro TB, Silva J, Sundaram M, et al. Longitudinal analyses reveal immunological misfiring in severe COVID-19. Nature. 2020;584(7821):463-9.

86. Verdecchia P, Cavallini C, Spanevello A, Angeli F. The pivotal link between ACE2 deficiency and SARS-CoV-2 infection. European journal of internal medicine. 2020.

87. Goyal P, Choi JJ, Pinheiro LC, Schenck EJ, Chen R, Jabri A, et al. Clinical characteristics of Covid-19 in New York city. N Engl J Med. 2020;382(24):2372-4.

88. Mercola J, Grant WB, Wagner CL. Evidence regarding vitamin D and risk of COVID-19 and its severity. Nutrients. 2020;12(11):3361.

89. Cao X. COVID-19: immunopathology and its implications for therapy. Nat Rev Immunol. 2020;20(5):269-70.

90. Yang D, Chu H, Hou Y, Chai Y, Shuai H, Lee AC-Y, et al. Attenuated interferon and proinflammatory response in SARS-CoV-2infected human dendritic cells is associated with viral antagonism of STAT1 phosphorylation. J Infect Dis. 2020;222(5):734-45.

91. Berlin DA, Gulick RM, Martinez FJ. Severe covid-19. N Engl J Med. 2020:383(25):2451-60.

92. Boaz M. Vitamin D and COVID-19: Partial Evidence. Bioactive Compounds in Health and Disease. 2021;4(3):40-4.

93. Whittemore PB. COVID-19 fatalities, latitude, sunlight, and vitamin D. Am J Infect Control. 2020;48(9):1042-4.
94. Ayoubkhani D, Nafilyan V, White C, Goldblatt P, Gaughan $\mathrm{C}$, Blackwell L, et al. Ethnic-minority groups in England and Wales-factors associated with the size and timing of elevated COVID-19 mortality: a retrospective cohort study linking census and death records. Int J Epidemiol. 2020.

95. Herrick KA, Storandt RJ, Afful J, Pfeiffer CM, Schleicher RL, Gahche JJ, et al. Vitamin D status in the United States, 20112014. Am J Clin Nutr. 2019;110(1):150-7.

96. Meftahi GH, Jangravi Z, Sahraei H, Bahari Z. The possible pathophysiology mechanism of cytokine storm in elderly adults with COVID-19 infection: the contribution of "inflame-aging." Inflamm Res. 2020;69(9):825-39.

97. Silberstein M. Correlation between premorbid IL-6 levels and COVID-19 mortality: Potential role for Vitamin D. International Immunopharmacology. 2020;88:106995.

98. Xu J, Yang J, Chen J, Luo Q, Zhang Q, Zhang H. Vitamin D alleviates lipopolysaccharide-induced acute lung injury via regulation of the renin-angiotensin system. Mol Med Rep. 2017;16(5):7432-8.

99. Bouillon R, Carmeliet G, Verlinden L, van Etten E, Verstuyf A, Luderer HF, et al. Vitamin D and human health: lessons from vitamin D receptor null mice. Endocr Rev. 2008;29(6):726-76.

100. Christakos S, Dhawan P, Verstuyf A, Verlinden L, Carmeliet G. Vitamin D: metabolism, molecular mechanism of action, and pleiotropic effects. Physiol Rev. 2016;96(1):365-408.

101. Li YC, Qiao G, Uskokovic M, Xiang W, Zheng W, Kong J. Vitamin $\mathrm{D}$ : a negative endocrine regulator of the renin-angiotensin system and blood pressure. J Steroid Biochem Mol Biol. 2004;89:387-92.

102. Jiang J-S, Chou H-C, Chen C-M. Cathelicidin attenuates hyperoxia-induced lung injury by inhibiting oxidative stress in newborn rats. Free Radical Biol Med. 2020;150:23-9.

103. Pittas AG, Chung M, Trikalinos T, Mitri J, Brendel M, Patel K, et al. Systematic review: vitamin D and cardiometabolic outcomes. Ann Intern Med. 2010;152(5):307-14.

104. Wang L, Song Y, Manson JE, Pilz S, März W, Michaëlsson K, et al. Circulating 25-hydroxy-vitamin D and risk of cardiovascular disease: a meta-analysis of prospective studies. Circulation: Cardiovascular Quality and Outcomes. 2012;5(6):819-29.

105. Brøndum-Jacobsen P, Benn M, Jensen GB, Nordestgaard BG. 25-hydroxyvitamin d levels and risk of ischemic heart disease, myocardial infarction, and early death: population-based study and meta-analyses of 18 and 17 studies. Arterioscler Thromb Vasc Biol. 2012;32(11):2794-802.

106. Bahrami LS, Ranjbar G, Norouzy A, Arabi SM. Vitamin D supplementation effects on the clinical outcomes of patients with coronary artery disease: a systematic review and meta-analysis. Sci Rep. 2020;10(1):1-10.

107. Levi M, Thachil J, Iba T, Levy JH. Coagulation abnormalities and thrombosis in patients with COVID-19. Lancet Haematol. 2020;7(6): e438-40.

108. Wu W-X, He D-R. Low vitamin D levels are associated with the development of deep venous thromboembolic events in patients with ischemic stroke. Clinical and applied thrombosis/hemostasis. 2018;24(9_suppl):69S-75S.

109. Khademvatani K, Seyyed-Mohammadzad MH, Akbari M, Rezaei Y, Eskandari R, Rostamzadeh A. The relationship between vitamin D status and idiopathic lower-extremity deep vein thrombosis. Int J Gen Med. 2014;7:303.

110. Kazemi A, Mohammadi V, Aghababaee SK, Golzarand M, Clark CCT, Babajafari S. Association of Vitamin D Status with SARSCoV-2 Infection or COVID-19 Severity: A Systematic Review and Meta-analysis. Adv Nutr. 2021.

111. Ilie PC, Stefanescu S, Smith L. The role of vitamin D in the prevention of coronavirus disease 2019 infection and mortality. Aging Clin Exp Res. 2020;32(7):1195-8. 
112. Faniyi AA, Lugg ST, Faustini SE, Webster C, Duffy JE, Hewison $\mathrm{M}$, et al. Vitamin D status and seroconversion for COVID-19 in UK healthcare workers. Eur Respir J. 2020.

113. Long QX, Liu BZ, Deng HJ, Wu GC, Deng K, Chen YK, et al. Antibody responses to SARS-CoV-2 in patients with COVID-19. Nat Med. 2020;26(6):845-8.

114. Castillo ME, Costa LME, Barrios JMV, Díaz JFA, Miranda JL, Bouillon R, et al. Effect of calcifediol treatment and best available therapy versus best available therapy on intensive care unit admission and mortality among patients hospitalized for COVID19: A pilot randomized clinical study. J Steroid Biochem Mol Biol. 2020;203:105751.

115. Rastogi A, Bhansali A, Khare N, Suri V, Yaddanapudi N, Sachdeva N, et al. Short term, high-dose vitamin D supplementation for COVID19 disease: a randomised, placebo-controlled, study (SHADE study). Postgraduate medical journal. 2020.

116. Murai IH, Fernandes AL, Sales LP, Pinto AJ, Goessler KF, Duran CS, et al. Effect of Vitamin D3 Supplementation vs Placebo on Hospital Length of Stay in Patients with Severe COVID-19: A Multicenter, Double-blind, Randomized Controlled Trial. medRxiv. 2020

117. Jungreis I, Kellis M. Mathematical analysis of Córdoba calcifediol trial suggests strong role for Vitamin D in reducing ICU admissions of hospitalized COVID-19 patients. medRxiv. 2020.

118. Abdollahi A, Kamali Sarvestani H, Rafat Z, Ghaderkhani S, Mahmoudi-Aliabadi M, Jafarzadeh B, et al. The association between the level of serum $25(\mathrm{OH})$ vitamin $\mathrm{D}$, obesity, and underlying diseases with the risk of developing COVID-19 infection: A case-control study of hospitalized patients in Tehran. Iran Journal of medical virology. 2021;93(4):2359-64.

119. Meltzer DO, Best TJ, Zhang H, Vokes T, Arora VM, Solway J. Association of Vitamin D Levels, Race/Ethnicity, and Clinical Characteristics With COVID-19 Test Results. JAMA Network Open. 2021;4(3):e214117-e.

120. Alguwaihes AM, Sabico S, Hasanato R, Al-Sofiani ME, Megdad $\mathrm{M}$, Albader SS, et al. Severe vitamin D deficiency is not related to SARS-CoV-2 infection but may increase mortality risk in hospitalized adults: a retrospective case-control study in an Arab Gulf country. Aging Clinical and Experimental Research. 2021:1-8

121. Butler-Laporte G, Nakanishi T, Mooser V, Morrison DR, Abdullah T, Adeleye O, et al. Vitamin D and COVID-19 susceptibility and severity in the COVID-19 Host Genetics Initiative: A Mendelian randomization study. PLoS Med. 2021;18(6):e1003605.

122. Singh S, Nimavat N, Singh AK, Ahmad S, Sinha N. Prevalence of Low Level of Vitamin D Among COVID-19 Patients and Associated Risk Factors in India-A Hospital-Based Study. Int J Gen Med. 2021;14:2523-31.

123. Ling SF, Broad E, Murphy R, Pappachan JM, Pardesi-Newton S, Kong M-F, et al. High-Dose Cholecalciferol Booster Therapy is Associated with a Reduced Risk of Mortality in Patients with COVID-19: A Cross-Sectional Multi-Centre Observational Study. Nutrients. 2020;12(12):3799.

124. Vassiliou AG, Jahaj E, Pratikaki M, Orfanos SE, Dimopoulou I, Kotanidou A. Low 25-Hydroxyvitamin D Levels on Admission to the Intensive Care Unit May Predispose COVID-19 Pneumonia Patients to a Higher 28-Day Mortality Risk: A Pilot Study on a Greek ICU Cohort. Nutrients. 2020;12(12):3773.

125. Cangiano B, Fatti LM, Danesi L, Gazzano G, Croci M, Vitale $\mathrm{G}$, et al. Mortality in an Italian nursing home during COVID-19 pandemic: correlation with gender, age, ADL, vitamin D supplementation, and limitations of the diagnostic tests. Aging (Albany NY). 2020;12(24):24522.

126. Charoenngam N, Shirvani A, Reddy N, Vodopivec DM, Apovian CM, Holick MF. Association of vitamin D status with hospital morbidity and mortality in adult hospitalized COVID-19 patients. Endocrine Practice. 2021.

127. Campi I, Gennari L, Merlotti D, Mingiano C, Frosali A, Giovanelli L, et al. Vitamin D and COVID-19 severity and related mortality: a prospective study in Italy. BMC Infect Dis. 2021;21(1):1-13.

128. Sulli A, Gotelli E, Casabella A, Paolino S, Pizzorni C, Alessandri E, et al. Vitamin D and Lung Outcomes in Elderly COVID-19 Patients. Nutrients. 2021;13(3):717.

129. Notz Q, Herrmann J, Schlesinger T, Kranke P, Sitter M, Stumpner J, et al. Vitamin D Deficiency in Critically Ill COVID-19 ARDS Patients. Clinical Nutrition. 2021.

130. Gaudio A, Murabito AR, Agodi A, Montineri A, Castellino P, Group DCR. Vitamin D Levels Are Reduced at the Time of Hospital Admission in Sicilian SARS-CoV-2-Positive Patients. Int J Environ Res Public Health. 2021;18(7):3491.

131. Bassatne A, Basbous M, Chakhtoura M, El Zein O, Rahme M, Fuleihan GE-H. The link between COVID-19 and VItamin D (VIVID): a systematic review and meta-analysis. Metabolism. 2021:154753.

132. Sooriyaarachchi P, Jeyakumar DT, King N, Jayawardena R. Impact of vitamin D deficiency on COVID-19. Clinical Nutrition ESPEN. 2021. https://doi.org/10.1016/j.clnesp.2021.05.011.

133. Wang R, DeGruttola V, Lei Q, Mayer KH, Redline S, Hazra A, et al. The vitamin D for COVID-19 (VIVID) trial: A pragmatic cluster-randomized design. Contemporary Clinical Trials. 2021;100:106176.

134. Trial of Vitamin D to Reduce Risk and Severity of COVID-19 and Other Acute Respiratory Infections (CORONAVIT) [Available from: https://clinicaltrials.gov/ct2/show/NCT04579640

135. Prevention and Treatment With Calcifediol of COVID-19 Induced Acute Respiratory Syndrome (COVIDIOL) [Available from: https://clinicaltrials.gov/ct2/show/NCT04366908

136. Jaun F, Lüthi-Corridori G, Abig K, Makhdoomi A, Haas P, Schuetz P, et al. High Dose Vitamin-D-substitution in patients with COVID-19: study protocol for a randomized, double blind, placebo controlled, multi-centre study-VitCov Trial. 2021.

137. Lips P. Worldwide status of vitamin D nutrition. J Steroid Biochem Mol Biol. 2010;121(1-2):297-300.

138. Cashman KD, Dowling KG, Škrabáková Z, Gonzalez-Gross M, Valtueña J, De Henauw S, et al. Vitamin D deficiency in Europe: pandemic? Am J Clin Nutr. 2016;103(4):1033-44.

139. Samefors M, Östgren CJ, Mölstad S, Lannering C, Midlöv P, Tengblad A. Vitamin D deficiency in elderly people in Swedish nursing homes is associated with increased mortality. Eur J Endocrinol. 2014;170(5):667-75.

140. Griffin TP, Wall D, Blake L, Griffin DG, Robinson SM, Bell M, et al. Vitamin D status of adults in the community, in outpatient clinics, in hospital, and in nursing homes in the West of Ireland. J Gerontol A. 2020;75(12):2418-25.

Publisher's Note Springer Nature remains neutral with regard to jurisdictional claims in published maps and institutional affiliations. 